\title{
Ventilator-Associated Pneumonia (VAP): Clinical Strategies, Treatment Challenges and Economic Concerns
}

\author{
Zubair $\mathrm{S}^{1}$, Ali $\mathrm{H}^{2 *}$, Zafar $\mathrm{F}^{3}$, Beg AE${ }^{1}$, Sial AA ${ }^{1}$, Naveed $\mathrm{S}^{4}$, Saleem $\mathrm{S}^{5}$ and Tariq $\mathrm{A}^{1}$ \\ ${ }^{1}$ Faculty of Pharmacy, Ziauddin University, Karachi, Pakistan \\ ${ }^{2}$ Faculty of Pharmaceutical Sciences, Jinnah Sindh Medical University, Karachi, Pakistan \\ ${ }^{3}$ Faculty of Pharmacy and Pharmaceutical Sciences, University of Karachi, Karachi, Pakistan \\ ${ }^{4}$ Faculty of Pharmacy, Jinnah University for Women, Karachi, Pakistan \\ ${ }^{5}$ National Institute of Cardiovascular Diseases (NICVD), Karachi, Pakistan
}

\begin{abstract}
The clinical and economic features of Ventilator-Associated Pneumonia (VAP) are quite unclear, with an extensive array of values and contradictory results. The real challenge in this connection is to present the real estimate of the clinical and associated economic consequences of VAP. In developing countries like Pakistan, it is important to formulate an optimal institutional antimicrobial policy that can be used as a guide for empirical/prophylactic and specific therapies of antibiotics in VAP with more rational approach to lessen the rates of mortality and morbidity, decline the length of treatment and hospitalization and the significant impact in prevention of development of multidrug resistant strains and cost reduction.
\end{abstract}

Keywords: Ventilator-Associated Pneumonia (VAP); Multidrug resistant; Clinical; Economic consequences

\section{Introduction}

Ventilator Associated Pneumonia (VAP) and Hospital-Acquired Pneumonia (HAP) are imperative basis of mortality and morbidity around the world. Rate of mortality has been reported up to $62 \%$. VAP and HAP are the succeeding cause of nosocomial contagion, however rate of such infections in the intensive care settings are documented with comparatively higher frequencies. VAP is defined as a subset of hospital acquired pneumonia which incorporates all patients receiving mechanical ventilation for more than $48 \mathrm{~h}$. VAP happen exclusively in the ICU settings [1]. It is the significant cause of mortality and morbidity around the globe in hospital settings. Considerable economic impact of VAP is endorsed to significant increased extent of hospital stay with high expenditures [2,3]. Diagnostic criteria of VAP are summarized in Table 1.

\section{Incidence}

According to the National Nosocomial Infections Surveillance (NNIS) report, the rate of VAP is documented 7.6 for each 1000 ventilator-days. The recurrence of the VAP was reported to be 22.8 for each 1000 patient days, 29.6 for each 1000 patient days at risk, 35.7 for every 1000 ventilator-days, and 44.0 for every 1000 ventilator-days at peril. It was also observed from NNIS statistics that the rate of VAP was most imperative for ICUs cases ( 15.2 for each 1000 ventilator-days). The general pervasiveness of VAP was $9.3 \%$. In a surveillance study carried out in Canada on a cohort of 1014 patients, who received ventilation

\begin{tabular}{|c|c|}
\hline Parameters & Diagnostic Criteria \\
\hline Temperature $\left({ }^{\circ} \mathrm{C}\right)$ & Between $38.5-38.9$ OR $\geq 39$ or $\leq 36$ \\
\hline Count of White blood cells $(\mathrm{WBC}) / \mathrm{mm}^{3}$ & $<4.000$ or $>11.000$ and $50 \%$ bands \\
\hline Secretions & purulent $(>25$ neutrophils/high-power field) \\
\hline $\begin{array}{c}\text { X-ray (Chest) permeates } \\
\text { Partial pressure of } \mathrm{O}_{2} \text { in arterial blood } \\
\left(\mathrm{PaO}_{2}\right) .\end{array}$ & $\begin{array}{c}\text { Disseminate (diffused)/irregular (patchy) } \\
\text { or confined (localized) }\end{array}$ \\
\hline $\begin{array}{c}\text { Sputum } \\
\text { Decreased; } \leq 240 \text { and no ARDS }\end{array}$ & Culture $>1+$ and same Gram staining \\
organisms
\end{tabular}

Table 1: The diagnostic criteria for VAP [4]. up to $48 \mathrm{~h}$ or more, depicted $17.4 \%(\mathrm{n}=177)$ with VAP. The onset of VAP was also tabulated with respect to ICU admission in this study and reported to be 7 days [4-10].

\section{Ventilator-Associated Pneumonia (VAP) in Children and Neonates}

A high incidence rate in children and neonates has been reported for VAP over the couple of years. Interestingly a contradictory value may also have been viewed as $1 / 1000$ ventilator-days to $63 / 1000$ ventilatordays in different literature across the variable geographical area. A reconnaissance study also evaluated the rate of VAP in teaching and non-teaching hospitals and reported higher rates in former [11]. The same study reported higher rates in lower-middle-income compared to upper-middle-income countries. A similar review revealed higher rates in lower-center salary contrasted with upper-center wage nations. Significantly high incidences were observed from India i.e., $36.2 \%$ and Egypt as $31.8 / 1000$ ventilator-days [12,13]. While a lower frequency was reported from USA and Germany [14-16]. A value of $23.6 \%$ of VAP incidence was reported from European origin 41 followed by $6.6 \%$ and $6.7 \%$ from Italy and Australia [17-19]. A challenging situation in relevance to the surveillance definitions in pediatric situation is due to the amalgamation of radiological and clinical scenarios which creates an excessively huge space for elucidation.

\section{Risk factors for VAP}

The existence of definite host, pharmacological or environmental factors can lead to increase propensity of VAP in critical care patients.

*Corresponding author: Huma Ali, Faculty of Pharmaceutical Sciences Jinnah Sindh Medical University, Karachi, Pakistan, Tel: 923002621917; E-mail: humaali80@live.com

Received April 14, 2017; Accepted May 29, 2017; Published June 08, 2017

Citation: Zubair S, Ali H, Zafar F, Beg AE, Sial AA, et al. (2017) VentilatorAssociated Pneumonia (VAP): Clinical Strategies, Treatment Challenges and Economic Concerns. J Bioequiv Availab 9: 432-436. doi: 10.4172/jbb.1000338

Copyright: ( 2017 Zubair S, et al. This is an open-access article distributed under the terms of the Creative Commons Attribution License, which permits unrestricted use, distribution, and reproduction in any medium, provided the original author and source are credited. 
Citation: Zubair S, Ali H, Zafar F, Beg AE, Sial AA, et al. (2017) Ventilator-Associated Pneumonia (VAP): Clinical Strategies, Treatment Challenges and Economic Concerns. J Bioequiv Availab 9: 432-436. doi: 10.4172/jbb.1000338

Risk factors identified from literature for the development of VAP have been detailed in Table 2 . These factors can be distinguished into nonmodifiable and modifiable risk factors $[11,20]$ (Table 2).

\section{Pathophysiology of VAP}

Pathophysiology of VAP is classified as the respiratory and digestive regions colonization and secreted micro aspiration of superior and inferior segments of airway [12]. Initiation of VAP is categorized into 2 forms:

a) Rapid onset: VAP associated with antibiotic-susceptible species and occurs within 48-96 h after intubation.

b) Late-onset: It is connected with resistant organisms and occurs more than $96 \mathrm{~h}$ after intubation [12].

The growing incidence of multi-resistant organisms in VAP and the mortality benefit related with initial appropriate treatment have emerged to an amplified use of wide spectrum antibiotics [13-16]. The requirement to balance such factors with augmented selection pressure for the resistance emergence has led to the development of the appropriate guidelines to optimize the diagnosis, treatment and management of VAP based on local patterns of susceptibility [17-20].

\section{Microbial Etiology}

Transcendence of certain destructive (virulent) microorganism strains in VAP has generated the concept of core pathogens. Such pathogens ought to be considered as potential reasons for VAP amongst the patients. This group of pathogens incorporate Streptococcus species, Streptococcus pneumoniae, Haemophilus influenzae, Enterobacteriaceae, like (Klebsiella, Proteus, Escherichia coli, Enterobacter, Serratia marcescens), and in addition methicillin-vulnerable Staphylococcus aureus [21-23] (Table 3).

\section{Treatment Strategies}

Overarching philosophy of VAP treatment is depicted by the following:

- Prompt commencement of empirical therapy.

- Association of the level of infectivity and clinical staging.

- Appropriate treatment to reduce mortality rates.

- Association of delayed onset of VAP with resistant isolates.

- Careful utilization of combination treatment for specific resistant pathogens (P. aeruginosa and MRSA) [24-26].

\section{Existing Guideline to Antimicrobial Selection in VAP}

According to the American Thoracic Society (ATS) and the Infectious Diseases Society of America (IDSA) guidelines (IDSA/ATS) recommended Antibiotic management of VAP is based on multiple interconnecting principles. The core of such idea proposes that treatment of VAP should be commenced as early as the diagnosis is entertained. In an attempt to reduce patient impairment and experience to unnecessary antibiotics resistance, utilization of antibiogram data is recommended to diminish the redundant use of twofold antibiotic treatment including gram-negative empiric methicillin-resistant Staphylococcus aureus (MRSA). Further stress on crash course of antimicrobial treatment for subjects with VAP sovereign of microbial etiology, in addition to deescalation of antibiotic has been accounted for. In specific situations, the appropriate regimen may diverge from the standard protocol in the IDSA/ATS guidelines44-46. Various treatment options have been summarized in the Table 4.

\begin{tabular}{|c|c|c|}
\hline \multirow[t]{2}{*}{ Host associated } & Non-modifiable risk factors & $\begin{array}{ll} & \text { Age } \\
: & \text { Sex } \\
: & \text { Medical conditions (Underlying) } \\
\text { - } & \text { Head trauma }\end{array}$ \\
\hline & Modifiable risk factor & $\begin{array}{ll} & \text { Intubations (number and frequency) } \\
\text { Time comparisons for circuit change (24 h vs. } 48 \mathrm{~h} \text { ) } \\
\text { - } \quad \text { Body position of patient } \\
\text { - Use of medications/antibiotic }\end{array}$ \\
\hline Device associated & & $\begin{array}{l}\text { Endotracheal tubing } \\
\text { - } \text { Orontilator circuit } \\
\text { Orogastric or Nasogastric tubes }\end{array}$ \\
\hline Personnel related & & $\begin{array}{l}\text { - Inappropriate hand washing practice } \\
\text { Poor gloves changing protocol during patients contact } \\
\text { Lack of use of personal protective utensils when antibiotic resistant } \\
\text { pathogens have been recognized }\end{array}$ \\
\hline
\end{tabular}

Table 2: Risk factors for VAP [15-18,24,34].

\begin{tabular}{|c|c|c|c|}
\hline Disease Condition & Categorization & Diagnostic Indications & Responsible Pathogens \\
\hline \multirow[t]{3}{*}{ VAP } & A-Group & $\begin{array}{c}\text { Absence of resistance, possible risk factors }{ }^{\dagger} \text { and mild } \\
\text { to moderate stage }{ }^{\ddagger}\end{array}$ & Core-organisms (pathogens) ${ }^{*}$ \\
\hline & B-Group & $\begin{array}{l}\text { Resistance risk factors } \dagger \\
\text { and severe stage }\end{array}$ & Core pathogens ${ }^{\star}, \mathrm{MRSA}$ and multi drug resistant organism ${ }^{\Omega}$ \\
\hline & C-Group & $\begin{array}{c}\text { Control; ICU patients/ventilated but not developed } \\
\text { VAP }\end{array}$ & - \\
\hline
\end{tabular}

"Core pathogens: Streptococcus pneumoniae, Haemophilus influenzae, Enterobacter species, Escherichia coli, Klebsiella, Proteus strains, and methicillin-susceptible Staphylococcus aureus MSSA.

פMulti drug resistant organism: Pseudomonas aeruginosa, netobacter, Legionella and Stenotrophomonas maltophilia strains.

${ }^{\dagger}$ Resistance risk factors embrace antibiotic treatment in last ninety (90) days and delayed inception $>5$ days during hospital stay.

łMild to moderate stage: no intubation, hypotension, sepsis, fast development of infiltrates or end organ damage.

§evere stage: presence of intubation, hypotension, sepsis, quick evolution of permeates and end-organ dysfunction.

Table 3: Group classification with respect to diagnostic features and pathogens [22-23,26,34]. 
Citation: Zubair S, Ali H, Zafar F, Beg AE, Sial AA, et al. (2017) Ventilator-Associated Pneumonia (VAP): Clinical Strategies, Treatment Challenges and Economic Concerns. J Bioequiv Availab 9: 432-436. doi: 10.4172/jbb.1000338

\begin{tabular}{|c|c|}
\hline Organism Responsible & Treatment Strategies \\
\hline $\begin{array}{l}\text { Antibiotics (Gram-Positive): MRSA } \\
\text { sensitive }\end{array}$ & $\begin{array}{l}\text { Glycopeptide } \\
\text { Vancomycin } 15 \mathrm{mg} / \mathrm{kg} \text { q8 to } 12 \mathrm{~h} \mathrm{IV} \\
\text { (consider a loading dose of } 25-30 \\
\mathrm{mg} / \mathrm{kg} \times 1 \text { for severe illness) } \\
\text { OR } \\
\text { Oxazolidinones Linezolid } 600 \mathrm{mg} \text { q12h IV }\end{array}$ \\
\hline $\begin{array}{l}\text { Antibiotics (Gram-Negative): Anti- } \\
\text { pseudomonal products: Non- } \beta \text {-Lactam } \\
\text { moities }\end{array}$ & $\begin{array}{l}\text { Fluoroquinolones } \\
\text { Ciprofloxacin } 400 \mathrm{mg} \text { q } 8 \mathrm{~h} \text { IV } \\
\text { Levofloxacin } 750 \mathrm{mg} \text { q24h IV } \\
\text { OR } \\
\text { Polymyxins } \\
\text { Colistin } 5 \mathrm{mg} / \mathrm{kg} \text { IV } \times 1 \text { (loading dose) } \\
\text { followed by } 2.5 \\
\mathrm{mg} \times(1.5 \times \mathrm{CrCl}+30 \text { ) IV q12h } \\
\text { (maintenance dose) } \\
\text { Polymyxin B } 2.5-3.0 \mathrm{mg} / \mathrm{kg} / \text { day divided in } \\
2 \text { daily IV doses } \\
\text { OR } \\
\text { Aminoglycosides } \\
\text { Amikacin } 15-20 \mathrm{mg} / \mathrm{kg} \text { q24h IV } \\
\text { Gentamicin } 5-7 \mathrm{mg} / \mathrm{kg} \text { q24h IV } \\
\text { Tobramycin } 5-7 \mathrm{mg} / \mathrm{kg} \text { q24h IV }\end{array}$ \\
\hline $\begin{array}{l}\text { Antibiotics (Gram-Negative) Anti- } \\
\text { pseudomonal range: } \beta \text {-Lactam- } \\
\text { moities }\end{array}$ & $\begin{array}{l}\text { Antipseudomonal penicillins } \\
\text { Piperacillin-tazobactam } 4.5 \mathrm{~g} \text { q6h IV } \\
\text { OR } \\
\text { Carbapenems } \\
\text { Imipenem } 500 \mathrm{mg} \text { q6hd IV } \\
\text { Meropenem } 1 \mathrm{~g} \text { q8h IV } \\
\text { OR } \\
\text { Cephalosporins } \\
\text { Cefepime } 2 \mathrm{~g} \text { q8h IV } \\
\text { Ceftazidime } 2 \mathrm{~g} \text { q8h IV } \\
\text { OR } \\
\text { Monobactams } \\
\text { Aztreonam } 2 \mathrm{~g} \text { q8h IV }\end{array}$ \\
\hline
\end{tabular}

Table 4: Recommended empiric treatment options for clinically suspected ventilator-associated pneumonia [47-50].

\section{Clinical Outcome Measures}

Clinical outcome of disease comprised of percent mortality rate with respect to age, duration of disease, pathogens (isolates) and comorbidities for VAP. Physiologic measures such as laboratory examination outcomes, health status and functionality characteristics of patient may be utilized as conclusive (clinical) measures [26-30].

\section{Economic Features of VAP}

The rate of mortality of VAP may increase from 27 to $43 \%$ if antibiotic resistant organisms are causative agent with 2-3 folds increment in hospital ICU stay [25,26]. Additional cost of VAP is calculated to be $\$ 40000$ per patient/hospital admission with specific ailment, with an approximated $\$ 1.2$ billion per annul cost $[3,27]$. In a recent study [23-29] the advancement of VAP was connected with an expansion of $\$ 41,294$ as average treatment charges per admission $(\$ 104,983 \pm \$ 91,080$ vs. $\$ 63,689 \pm \$ 75,030$ with $\mathrm{P}$ values $<0.001)$. To rationalize the optimal economic outcome of specific disease, various pharmacoeconomic evaluation methods are utilized including cost utilization, cost effectiveness, cost benefit and cost utility analyses. Pharmacoeconomic is the field which assesses the experimental and economic features of health care products, services and plans to health care providers, patients and policy makers $[28,29]$. These methods provide the means to compare the treatment options. The decision of perspective from which the analysis should be conducted, is an important consideration in pharmacoeconomic analysis. At present the pharmacoeconomic evaluation is valuable in individual patient treatment, total cost of care, resource allocation, and effective formulary management [29-31].

\section{Assessment of VAP}

Clinical Pulmonary Infection Score (CPIS) as a marker of diagnosis can be used to measure the progress of VAP. The value of CPIS is estimated by assigning points $(0,1$, and 2$)$ for various conditions of pneumonia including fever and level of oxygenation defacement [32]. Acute Physiological Assessment A and Chronic Health Evaluation (APACHE II SCORE) can be used as a vital factor to stratify the degree of risk for progression of VAP and to predict the possible rate of mortality [26,33-39].

\section{Measures Commonly Taken to Prevent VAP}

Effective projects consolidated different mediations, for example, practice of hand sanitation, use of gloves and sterilized gown for endotracheal tube control, elevation of backrest position, use of chlorhexidine as oral care product, prophylaxis for ulcers stress, and evasion of gastric over distension, a suitable maintenance of cuff pressure, insertion of oro-gastric tubes, and disposal of unnecessary tracheal suction [40-45]. Numerous stratagems have been illustrated to accomplish the various objectives including the incidence and risk of VAP and reduction in days of ventilation including Non-invasive Positive Pressure Ventilation (NPPV), weaning trials, sedation episodes, re-intubation avoidance, and an early tracheostomy. At the point when connected as a multimodal procedure by an interdisciplinary group, these intercessions are destined to be fruitful among children's and adults and have demonstrated viability in various regions of the world [46-52].

\section{Conclusion}

It is need of time to identify trends and set therapeutic priorities in the interests of patients with effective management of drug therapy at relatively affordable cost. Moreover, a strategic plan based on the existing statistics, specialist view and contemporary practice for the stipulation of patient care should be established to evaluate risk stratification factors and to facilitate correct diagnosis, treatment rationale and improve cure for challenging pathogens with decrease morbidity and better survival. It is also recommended to conduct related studies to assess the frequency and location of associated risks in local population. Results of these investigations may benefit the seriously ill ICU patients receiving mechanical ventilation by improving the clinical outcomes. Furthermore, pharmacoeconomic studies can also be effectively used to save the economic resources, and thus satisfy patient's needs at optimal rate.

\section{References}

1. Richards MJ, Edwards JR, Culver DH, Gaynes RP (1999) Nosocomial infections in medical intensive care units in the United States. Crit Care Med 27: 887-892.

2. Chastre J (2005) Conference summary: ventilator-associated pneumonia Respir Care 50: 975-983.

3. Augustyn B (2007) Ventilator-associated pneumonia risk factors and prevention. Crit Care Nur 27: 32-39.

4. American Thoracic Society; Infectious Diseases Society of America (2005) Guidelines for the management of adults with hospital-acquired, ventilatorassociated, and healthcare-associated pneumonia. Am J Respir Crit Care Med 171: 388-416.

5. Lizioli A, Privitera G, Alliata E, Banfi EA, Boselli L, et al. (2003) Prevalence of nosocomial infections in Italy: result from the Lombardy survey in 2000. J Hosp Infect 54: 141-148.

6. National Nosocomial Infections Surveillance System (2004) National Nosocomial Infections Surveillance (NNIS) System Report, data summary from January 1992 through June 2004, issued October 2004. Am J Infect Control 32: $470-485$. 
Citation: Zubair S, Ali H, Zafar F, Beg AE, Sial AA, et al. (2017) Ventilator-Associated Pneumonia (VAP): Clinical Strategies, Treatment Challenges and Economic Concerns. J Bioequiv Availab 9: 432-436. doi: 10.4172/jbb.1000338

7. Eggimann P, Hugonnet S, Sax H, Touveneau S, Chevrolet JC, et al. (2003) Ventilator-associated pneumonia: caveats for benchmarking. Intensive Care Med 29: 2086-2089.

8. Cook DJ, Walter SD, Cook RJ, Griffith LE, Guyatt GH, et al. (1998) Incidence of and risk factors for ventilator-associated pneumonia in critically ill patients. Ann Intern Med 129: 433-440.

9. Rello J, Ollendorf DA, Oster G, Vera-Llonch M, Bellm L, et al. (2002) Epidemiology and outcomes of ventilator-associated pneumonia in a large US database. Chest 122: 2115-2121.

10. Markowicz P, Wolff M, DjedaÏni K, Cohen Y, Chastre J, et al. (2000) Multicenter prospective study of ventilator-associated pneumonia during acute respiratory distress syndrome: incidence, prognosis, and risk factors. Am J Respir Crit Care Med: 1942-1948.

11. Rosenthal VD, Jarvis WR, Jamulitrat S, Silva CP, Ramachandran B, et al. (2012) Socioeconomic impact on device-associated infections in pediatric intensive care units of 16 limited-resource countries: international Nosocomial Infection Control Consortium findings. Pediatr Crit Care Med 13: 399-406.

12. Awasthi S, Tahazzul M, Ambast A, Govil YC, Jain A (2013) Longer duration of mechanical ventilation was found to be associated with ventilator-associated pneumonia in children aged 1 month to 12 years in India. J Clin Epidemiol 66: 62-66.

13. Rasslan O, Seliem ZS, Ghazi IA, El Sabour MA, El Kholy AA, et al. (2012) Device-associated infection rates in adult and pediatric intensive care units of hospitals in Egypt. International Nosocomial Infection Control Consortium (INICC) findings. J Infect Public Health 5: 394-402.

14. Geffers C, Baerwolff S, Schwab F, Gastmeier P (2008) Incidence of healthcareassociated infections in high-risk neonates: results from the German surveillance system for very-low-birthweight infants. J Hosp Infect 68: 214-221.

15. Leistner R, Piening B, Gastmeier P, Geffers C, Schwab F (2013) Nosocomial infections in very low birthweight infants in Germany: current data from the National Surveillance System NEO-KISS. Klin Padiatr 225: 75-80.

16. Edwards JR, Peterson KD, Andrus ML, Dudeck MA, Pollock DA, et al. (2008) National Healthcare Safety Network (NHSN) report, data summary for 2006 through 2007, issued November 2008. Am J Infect Control 36: 609-626.

17. Raymond J, Aujard Y (2000) Nosocomial Infections in Pediatric Patients A European, Multicenter Prospective Study. Infect Control Hosp Epidemiol 21: 260-263

18. Patria MF, Chidini G, Ughi L, Montani C, Prandi E, et al. (2013) Ventilatorassociated pneumonia in an Italian pediatric intensive care unit: a prospective study. World J Pediatr 9: 365-368.

19. Gautam A, Ganu SS, Tegg OJ, Andresen DN, Wilkins BH, et al. (2012) Ventilator-associated pneumonia in a tertiary paediatric intensive care unit: a 1-year prospective observational study. Crit Care Resusc 14: 283.

20. Singh N, Rogers P, Atwood CW, Wagener MM, Yu VI (2000) short-course empiric antibiotic therapy for patients with pulmonary infiltrates in the intensive care unit. Am J Respir Crit Care Med 162: 505-511.

21. Karaoglan H, Yalcin AN, Cengiz M, Ramazanoglu A, Ogunc D, et al. (2010) Analysis of ventilator-associated pneumonia in Turkish medical-surgical intensive care units. Infez Med 4: 248-255.

22. Rotstein C, Evans G, Born A, Grossman R, Light RB, et al. (2008) Clinical practice guidelines for hospital-acquired pneumonia and ventilator-associated pneumonia in adults. Can J Infect Dis Med Microbiol 19: 19-53.

23. Gupta A, Agrawal A, Mehrotra S, Singh A, Malik S, et al. (2011) Incidence, risk stratification, antibiogram of pathogens isolated and clinical outcome of ventilator associated pneumonia. Indian J Crit Care Med 15: 96.

24. Jayanthi MK, Sushma NV (2014) Drug Utilization Pattern and Pharmacoeconomic Study in Paediatric Dentistry at a Tertiary Hospital. Inter J Pharm Pharma Sci 6: 70-72.

25. Ruíz M, Torres A, Ewig S, Marcos MA, Alcón A, et al. (2000) Noninvasive versus invasive microbial investigation in ventilator-associated pneumonia: evaluation of outcome. Am J Respir Crit Care Med 162: 119-125.

26. Lauzier F, Ruest A, Cook D, Dodek P, Albert M, et al. (2008) The value of pretest probability and modified clinical pulmonary infection score to diagnose ventilator-associated pneumonia. J Crit Care 23: 50-57.

27. Marya DZ, Andrew FS (2010) Ventilator-Associated Pneumonia: The Clinical
Pulmonary Infection Score as a Surrogate for Diagnostics and Outcome. Clin Infec Dis 51: 131-135.

28. Cunnion KM, Weber DJ, Broadhead WE, Hanson LC, Pieper CF, et al (1996) Risk factors for nosocomial pneumonia: Comparing adult critical-care populations. Am J Respir Crit Care Med 153: 158-162.

29. Kalanuria AA, Ziai W, Mirski M (2014) Ventilator-associated pneumonia in the ICU. Crit Care 18: 208.

30. Diaz O, Diaz E, Rello J (2003) Risk factors for pneumonia in the intubated patient. Infect Dis Clin North Am 17: 697-705.

31. Rocha LA, Vilela CA, Cezario RC, Almeida AB, Gontijo FP (2008) Ventilatorassociated pneumonia in an adult clinical-surgical intensive care unit of a Brazilian university hospital: incidence, risk factors, etiology, and antibiotic resistance. Braz J Infect Dis 12: 80-85.

32. Kunis KA, Puntillo KA (2003) Ventilator-associated pneumonia in the ICU: its pathophysiology, risk factors, and prevention. Am J Nurs 133: 64-64.

33. Tablan OC, Anderson LJ, Besser R, Bridges C, Hajjeh R (2004) Guidelines for preventing healthcare-associated pneumonia, 2003. MMWR 53: 1-36.

34. Kollef MH, Micek ST (2005) Strategies to prevent antimicrobial resistance in the intensive care unit. Crit Care Med 33: 1845-1853.

35. Marelich GP, Murin S, Battistella F, Inciardi J, Vierra T, et al. (2000) Protocol weaning of mechanical ventilation in medical and surgical patients by respiratory care practitioners and nurses: effect on weaning time and incidence of ventilator-associated pneumonia. Chest 118: 459-467.

36. Maquelin K, Kirschner C, Choo-Smith LP, Ngo-Thi NA, Vreeswijk V, et al. (2003) Prospective study of the performance of vibrational spectroscopies for rapid identification of bacterial and fungal pathogens recovered from blood cultures. $\mathrm{J}$ Clin Microbiol 41: 324-329.

37. Koenig SM, Truwit JD (2006) Ventilator-associated pneumonia: diagnosis treatment, and prevention. Clin Micro Rev 19: 637-657.

38. Grossman RF, Fein A (2009) Evidence-based assessment of diagnostic tests for ventilator-associated pneumonia executive summary. Chest 117: 177-181.

39. Shorr AF, Sherner JH, Jackson WL, Kollef MH (2005) Invasive approaches to the diagnosis of ventilator-associated pneumonia: a meta-analysis. Crit Care Med 33: 46-53.

40. Chastre J, Wolff M, Fagon JY, Chevret S, Thomas F, et al. (2003) Comparison of 8 vs 15 days of antibiotic therapy for ventilator-associated pneumonia in adults: a randomized trial. JAMA 290: 2588-2598.

41. Vincent JL (2004) Ventilator-associated pneumonia. J Hosp Infect 57: 272-280.

42. Leroy O, Soubrier S (2004) Hospital-acquired pneumonia: Risk factors, clinical features, management, and antibiotic resistance. Curr Opin Pulm Med 10: 171-175.

43. Chen KY, Ko SC, Hsueh PR, Luh KT, Yang PC (2001) Pulmonary fungal infection: emphasis on microbiological spectra, patient outcome, and prognostic factors. Chest 120: 177-184.

44. Pittet D, Zingg W (2010) Reducing ventilator-associated pneumonia: when process control allows outcome improvement and even benchmarking. Crit care med 38: 983-984.

45. Aelami MH, Lotfi M, Zingg W (2014) Ventilator-associated pneumonia in neonates, infants and children. J Clin Diagn Res 3: 30.

46. Keyt H, Faverio P, Restrepo MI (2014) Prevention of ventilator-associated pneumonia in the intensive care unit: a review of the clinically relevant recent advancements. Indian J Med Res 139: 814

47. Garonzik SM, Li J, Thamlikitkul V, Paterson DL, Shoham S, et al. (2011) Population pharmacokinetics of colistin methanesulfonate and formed colistin in critically ill patients from a multicenter study provide dosing suggestions for various categories of patients. Antimicrob Agents Chemother 55: 3284-3294.

48. Nation RL, Li J, Cars O, Couet W, Dudley MN et al. (2005) Framework for optimisation of the clinical use of colistin and polymyxin B: the Prato polymyxin consensus. Lancet Infect Dis 15: 225-234.

49. Sader HS, Rhomberg PR, Jones RN (2005) In vitro activity of $\beta$-Lactam antimicrobial agents in combination with Aztreonam tested against metallob- $\beta$ lactamase-producing Pseudomonas aeruginosa and Acinetobacter baumannii. J Chemother 17: 622-627. 
Citation: Zubair S, Ali H, Zafar F, Beg AE, Sial AA, et al. (2017) Ventilator-Associated Pneumonia (VAP): Clinical Strategies, Treatment Challenges and Economic Concerns. J Bioequiv Availab 9: 432-436. doi: 10.4172/jbb.1000338

50. Kalil AC, Metersky ML, Klompas M, Muscedere J, Sweeney DA, et al. (2016) Management of adults with hospital-acquired and ventilator-associated pneumonia: 2016 clinical practice guidelines by the infectious diseases society of america and the american thoracic society. Clin Infect Dis 63: e61.

51. Bloos F, Müller S, Harz A, Gugel M, Geil D, et al. (2009) Effects of staff training on the care of mechanically ventilated patients: a prospective cohort study. $\mathrm{Br}$ J Anaesth 103: 232-237.

52. Salahuddin N, Zafar A, Sukhyani L, Rahim S, Noor MF, et al. (2004) Reducing ventilator-associated pneumonia rates through a staff education programme. $J$ Hosp Infect 57: 223-227. 